\title{
David's flight from Jerusalem according to Josephus
}

\author{
C T Begg (The Catholic University of America) ${ }^{1}$ \\ Research Associate: Department of Old Testament Studies \\ University of Pretoria
}

\begin{abstract}
2 Samuel 15:13-16:14 tells of David's flight from Jerusalem to the Jordan in the face of his son Absalom's rebellion and of the five encounters that occur during that journey. This article focuses on Josephus' retelling of the episode in his Ant 7.198-210. The article's detailed comparison between the Samuel passage and its Josephan version aims to find answers to such questions as: Which of 2 Samuel 15:13-16:14 text-forms(s) did Josephus utilize? What rewriting techniques has he applied to the data of his source and what is distinctive about his own resultant rendering? Finally, how does Josephus' handling of the Scriptural data in this case compare with how the data is treated elsewhere in early Jewish and Christian tradition?
\end{abstract}

\section{INTRODUCTION}

2 Sm 15:13-16:14 tells a poignant story of King David's flight from Jerusalem to the Jordan in the face of his son Absalom's revolt and of a series of five encounters which David has during his flight. ${ }^{2}$ In this essay I wish to examine the retelling of the episode by Josephus in his Antiquitates Judaicae (hereafter Ant) 7.198-210. ${ }^{3}$ I undertake this investigation with three overarching questions in mind: (1) In view of the differences among the ancient witnesses

\footnotetext{
${ }^{1} \mathrm{Dr}$ C T Begg, Professor at the School of Theology and Religious Studies, The Catholic University of America (Washington, DC) and editor of Old Testament Abstracts (OTA), is a research associate of Prof Dr Dirk J Human, Programme Manager, Biblical and Religious Studies, Faculty of Theology, University of Pretoria.

${ }^{2}$ On 2 Sm 15:13-16:14 I have consulted the commentaries of McCarter (1984), Anderson (1989), and Caquot and de Robert (1994) (see also Polzin 1993; Simpson 1997)

${ }^{3}$ For the text and translation of Ant 7.198-210 I use Marcus (1934:464-473). I have likewise consulted the text and translation of and notes on the passage in Nodet $\left(2001: 178-183^{*}\right)$ and the annotated translation of Begg (2005:260-264).
} 


\section{David's flight from Jerusalem}

for the text of $2 \mathrm{Sm} 15: 13-16: 14$, that is MT (BHS), $4 \mathrm{QSam}^{\mathrm{C}}{ }^{4}{ }^{4}$ the Codex Vaticanus (hereafter $B)^{5}$ and the Antiochene or Lucianic (hereafter $L$ ) manuscripts ${ }^{6}$ of the $L X X$, the Vetus Latina (hereafter $\left.V L\right),{ }^{7}$ the Vulgate (hereafter Vulg) ${ }^{8}$ and Targum Jonathan of the Former Prophets (hereafter $\mathrm{Tg}){ }^{9}$ what can be ascertained about the text-form(s) of the passage utilized by Josephus? (2) Which rewriting techniques has the historian applied to the data of his Vorlage $(n)$ and what is distinctive about his resulting version of the episode? Finally, (3) how does the Josephan handling of the biblical narrative compare with the treatment of it elsewhere in early Jewish and Christian tradition?

In conducting my comparison between them I divide up the material of

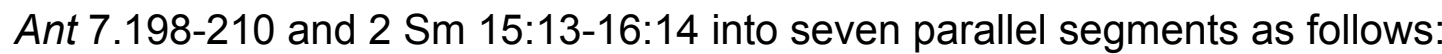
(1) Departure from Jerusalem (7.198-199// 15:13-18); (2) Encounter with clergy (7.200-201a// 15:24-29); (3) Encounter with Ittai (7.201b// 15:19-23); (4) Encounter with Hushai (7.202-204// 15:30-37); (5) Encounter with Ziba (7.205206// 16:1-4); (6) Encounter with Shimei (7.207-210a// 16:5-13); and (7) Arrival at the Jordan (7.210b// 16:14).

\section{SAMUEL AND JOSEPHUS COMPARED}

\subsection{Departure from Jerusalem}

David's flight from Jerusalem is precipitated in $2 \mathrm{Sm} 15: 13$ by a messenger's (direct-address) report to him ("the hearts of the men of Israel have gone after Absalom"), a report to which David responds in 15:14 by informing his servants that it is imperative that they all flee Jerusalem to avoid capture by the rebel. Josephus (7.198) formulates the news brought David impersonally and generalizes its content: "When these things were reported to David ...."

\footnotetext{
${ }^{4}$ For the (fragmentary) readings of 2 Sm 15:13-16:14 in 4QSama I use Cross et al (2005:156160) and for the translation Abegg, Flint \& Ulrich (1999:252-253). The extant readings (i e $15: 20-23,26-31 ; 15: 37-16: 2 ; 16: 6-8,10-13)$ of this manuscript differ minimally from the MT text of our passage.

${ }^{5}$ For the B text of 2 Sm (2 Rgns) 15:13-16:14 I use Brooke, Maclean \& Thackeray (1928:156162).

${ }^{6}$ For the Antiochene/Lucianic text of 2 Sm; (2 Rgns) 15:13-16:14 I use Fernández Marcos and Busto Saiz (1989:132-136).

${ }^{7}$ For the (fragmentary) VL readings in 2 Sm 15:13-16:14, see Morano (1989:44-45).

${ }^{8}$ For the Vulgate text of 2 Sm 15:13-16:14 I use Gryson (1994:438-440).

${ }^{9}$ For the targumic text of $2 \mathrm{Sm} ; 15: 13-16: 14$ I use Sperber (1959:186-188) and for the translation Harrington \& Saldarini (1987:187-189).
} 
Thereafter, he inserts ${ }^{10}$ an extended segment concerning the king's state of mind in the face of the report:

.... and he heard of these unexpected acts of his son, he was both

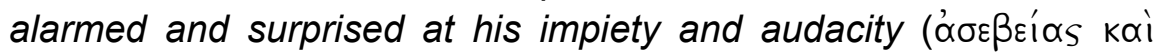
Tó $\lambda \mu n s)^{11}$ for Absalom was not even mindful of having been

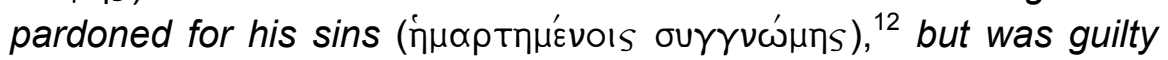

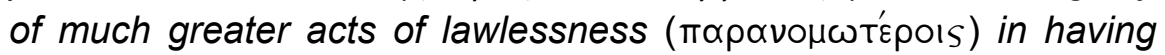
designs upon the kingship, which in the first place, had not (ou) $)^{13}$ been given him by $\mathrm{God}^{14}$ and, in the second place, involved the removal of his parent.

Following the above insertion, Josephus picks up on David's opening statement as cited in 15:14 ("arise and let us flee"). Whereas, however, in the biblical presentation the king addresses this word to "all his servants" (see 15:13), the historian renders it as an internal decision of the king who likewise mentally determines a terminus for his projected flight: "He therefore decided to flee to the country across the Jordan." "15

Having called on his servants to "flee" at the opening of 15:14, David continues with additional words to them in the remainder of the verse. In Josephus' presentation there has been no mention hitherto of an audience for the king's reactions to the report of Absalom's report received by him. Accordingly, at this point (7.199a), he inserts a reference to David's assembling a group of persons before continuing with his own version of the exchange between David and his "servants" recorded in 15:14-15: "And he

\footnotetext{
${ }^{10}$ Here and in what follows I italicize elements of Josephus' presentation which lack an explicit counterpart in $2 \mathrm{Sm}$ 15:13-16:14 itself.

${ }^{11}$ This is Josephus' only use of the above collocation. With the hendiadys ("audacious impiety") Josephus introduces a moral evaluation of Absalom's deed. By contrast the Bible itself presents the prince's initiative in neutral terms.

${ }^{12}$ The reference here it to David's reconciliation with Absalom following the rift caused by the latter's killing of his half-brother Amnon as described in Ant 7.193 (// $2 \mathrm{Sm}$ 14:33). Josephus' juxtaposition of Absalom's "audacious impiety" with his father's previous pardoning of him serves to highlight the wrongfulness of Absalom's deed.

${ }^{13}$ This negative particle is absent in the codices RO. It is read on the basis of the codices MSP by Marcus and Nodet (who points out that in the RO reading the sense would be "the kingship which had been given by God to David").

${ }^{14}$ With this phrase Josephus gives an added theological dimension to Absalom's misdeed this involved an attempted seizure of what God himself had allotted to another.

${ }^{15}$ This appendix to David's opening "flight word" of 15:14 accentuates the king's capacity to think matters through in a difficult situation - his decision is not simply to "flee" but to flee to a definite locale, as in fact he ends up doing (see 7.210b).
} 


\section{David's flight from Jerusalem}

called together his closest friends, ${ }^{16}$ and, having taken counsel with them ${ }^{17}$ concerning his son's madness ( $\alpha$ movoí $\alpha$ ) ${ }^{18}{ }^{18}$ committed the entire matter into the hands of God as judge."19

In 15:15 the king's servants respond to David's words to them (15:14) with a declaration of their readiness to do whatever he may decide. Given perhaps that such loyalty might be presumed on the part of the king's "closest friends" (see above), Josephus leaves their response to David's communications to them unmentioned. Instead, he proceeds immediately to recount the royal party's departure from Jerusalem as related in 15:16-18. The first moment (15:16) in this process involves David's arrangements regarding a group of women whom he leaves behind "to keep the house", that is "ten (VL 20) concubines". Josephus (7.199b) formulates equivalently: "Then,

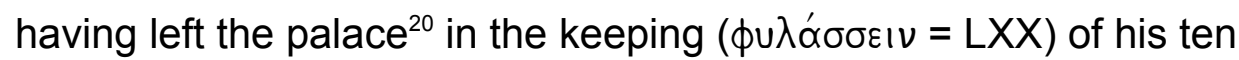
concubines ...." 21 Sm 15:16-17 makes double mention of David's leaving Jerusalem, the first time (15:16a) in company of "all his house(hold)," the second (15:17a) with "all the people" (MT LXX L; all his servants, LXX B), 15:17b adding that the party "halted at the last house" (MT LXX B; LXX L VL: at the wild olive in the wilderness; Tg: in a distant place; Vulg: far from the house). ${ }^{22}$ Thereafter, 15:18 enumerates four groups who pass before the king:

\footnotetext{
${ }^{16}$ This more select group is Josephus' replacement for the "servants" to whom David addresses his words in 15:14.

${ }^{17}$ This allusion to David's deliberating with his friends about the crisis might be inspired by the king's use of the term "us" in his words to the servants of 15:14: ("let us flee ... there will be no escape for us ... lest he [Absalom] ... bring down evil upon us") that includes the servants in the king's calculations.
}
${ }^{18}$ This indication concerning the content of the deliberations between David and his friends has no counterpart in the king's words to the servants in 15:14. The reference to the "madness" of Absalom's initiative echoes the negative qualification of his deed in terms of its "impiety and audacity" in 7.198.

\footnotetext{
${ }^{19}$ This reference to David's entrusting his cause to God has no counterpart in the king's words as cited in 15:14 where the Deity is nowhere mentioned. On the other hand, they do read like an anticipation of the subsequent declarations of resignation and trust attributed to the biblical David in the course of his flight (see 15:25-26;16:10-12). In Josephus' presentation such piety marks David's response to Absalom's revolt right from the start.

${ }^{20} 2 \mathrm{Sm}$ 15:16b speaks more generally of "the (LXX L his, i e David's) house."

${ }^{21}$ In 15:16b the reference is to "ten women of the concubines", implying that David had more then just ten concubines.

${ }^{22}$ Num Rab 3.2 takes the reference to the "last (literally far, מרחק) house" in 2 Sm 15:17 as an allusion to David's being "far from God," that is temporarily excommunicated due to his sin with Bathsheba. The same midrash finds an additional allusion to David's excommunicated status in the notice on his head being "covered" in 15:30.
} 
"all his servants, all the Cherethites, all the Pelethites [LXX B makes double mention of these two groups; Tg: all the archers and all the slingers] and the six hundred Gittites who had followed him from Gath." Josephus' version compresses: "... he departed from Jerusalem, with a large number who were eager ( $\pi \rho \circ \theta \dot{u} \mu \omega \varsigma$ ) ${ }^{23}$ to accompany him, ${ }^{24}$ and also the six hundred armed men who had taken part in his former flight in the lifetime of Saul."

\subsection{Encounter with clergy}

In the biblical account, the fugitive David encounters first "Ittai the Gittite" (2 Sm 15:19-23) and then the clerical carriers of the ark (15:24-29). Josephus reverses this sequence, perhaps in view of the greater significance of the latter encounter for the further course of the story, telling of David's meeting the ark's attendants in 7.200-201a.

According to (MT LXX B) 2 Sm 15:24a, David is approached by Zadok, the Levites and Abiathar; $L X X L$ does not mention the last of these personages. Once its attendants set the ark down (15:24b), David addresses (15:25) Zadok (alone), instructing him to return the ark to the city and alluding to the possibility of the Lord's bringing him back there himself. Once again, the historian offers (7.200a) a compressed rendering of the Bible's account: "But

\footnotetext{
${ }^{23}$ This word is absent in the codices RO, but is read by Marcus (1934) and Nodet (2001).

${ }^{24}$ With this formula Josephus encompasses all the various groups cited in 15:16-18 other than the last of these (the Gittites). His allusion to their "eagerness" to accompany the king may be inspired by the declaration - not reproduced by him as such (see above) - attributed to the royal servants in $15: 15$ where, responding to David's call to flight (15:14) they aver: "behold, your servants are ready to do whatever my lord the king decides." Josephus' generalizing of the biblical catalogue of those who accompany David goes together with his reduction of the double mention of the king's departing the city $(15: 16 a \alpha, 17 \mathrm{a} \alpha)$ to a single one and omission of the extraneous detail about the party's halting "at the last house" (15:17b, MT LXX B).

${ }^{25}$ The above identification of the "600" replaces the designation of them used in $15: 18$, that is "(600) Gittites who had followed him [David] from Gath." In the Bible's presentation the 600 would seem to be ethnic non-Israelites ("Gittites") who had joined David at the time of his sojourn in Gath. Josephus makes the 600 rather a group of David's (Israelite) supporters who, initially numbering 400 , associated themselves with the fugitive David at an earlier point,that is during his stay "at the cave of Adullam" (see $1 \mathrm{Sm} \mathrm{22:1-2//} \mathrm{Ant} \mathrm{6.248)} \mathrm{and} \mathrm{who} \mathrm{later} \mathrm{(see} 1$ $\mathrm{Sm} 25: 13 / / 6.299$ ) increase to 600 - the number of men David brought with him to Gath according to $1 \mathrm{Sm} \mathrm{27:2} \mathrm{(Ant} \mathrm{6.319).}$
} 
Abiathar ${ }^{26}$ and Sadok, the high priests, ${ }^{27}$ who had intended to depart with him, ${ }^{28}$ and all the Levites ${ }^{29}$ he persuaded to remain behind with the ark, ${ }^{30}$ for, God, he said, would deliver him even if it were not brought along." 31

In 2 Sm 15:27 David issues Zadok an additional order: he is to return to the city "in peace" along with his son Ahimaaz and Jonathan the son of Abiathar while David himself (15:27) will await word from Zadok at "the fords (ketiv, qere: steppes) of the wilderness." Leaving aside David's command to Zadok of 15:27 as duplicative of what has already been told him, the historian has the king rather (7.201a) enjoin all the assembled clergy to keep him informed: "He also instructed them to report to him secretly everything that

\footnotetext{
${ }^{26}$ In mentioning this figure in first place, Josephus diverges from the order of MT LXX B 15:24 where the phrase "Abiathar went up" (or possibly Abiathar "offered sacrifice" [Hebrew ויעל B]) appears quite abruptly after the mention of Zadok and the Levites' setting down the ark (Abiathar is not mentioned in LXX L 15:24; see above). Pseudo-Jerome (q.154) understands the Vulgate's phrase "ascendit Abiathar" in 15:24 as referring to the priest's "praying." When there is no divine response to his prayer, David commands that the ark be brought back to Jerusalem (see 15:25). In the same line, Jewish tradition (see $b$ Sot 48b; $b$ Yoma 73b; $S$ Olam Rab 14.3) avers that on this occasion Abiathar was unable to obtain a response from the Urim and the Thummim, whereas Zadok did suceed. The result was that David removed Abiathar from the priesthood and replaced him with Zadok.
}

${ }^{27}$ In (MT LXX B) 15:24 Zadok and Abiathar are mentioned without titles. Josephus cites David's choice of Sadok to be "high priest" along with his (David's) "friend" Abiathar in Ant 7.110 (cf 2 Sm 8:17).

${ }^{28}$ Josephus supplies this motivation for the priests' presence on David's flight route.

${ }^{29}$ The mention of these figures alongside Zadok (and Abiathar) in 15:24 is often regarded as an interpolation, inspired by the Priestly prescription (Num 4:4-15) concerning the Levites as the designated carriers of the ark; see the commentaries cited in $n 1$. In any case, Josephus does follow MT LXX BL in noting their presence, whereas, according to some authors (see, e g, Feldman 1998:62), his retelling of biblical history evidences an overall tendency to minimalize the Levites' role in favor of that of (his own) priestly group. From his rearranged version of 15:24 Josephus omits the concluding reference to the attendants' setting the ark down "until the people had all passed out of the city."

${ }^{30}$ In 2 Sm 15:25a David issues an order to Zadok (alone): "Carry the ark back into the city (LXX L adds: and set it down in its place)." Josephus depicts a less peremptory, "persuasive" David who, moreover addresses himself to all the ark's attendants - not just Zadok. He likewise recasts the biblical king's direct discourse as indirect in accord with his frequent practice, on which see Begg (1993:12-13, n 38).

${ }^{31}$ Compare David's statement to Zadok in 15:25b: "If I find favor in the eyes of the Lord, he will bring me back and let me see both it [the ark] and his habitation." Josephus' version eliminates the hypothetical formulation used by the biblical king, thereby heightening the selfconfidence of David's words (In the same line, he passes over the attached alternative formulation of 15:26: "but if he [God] says, 'I have no pleasure in you,' behold let him do to me what seems good to him.") His rendering likewise eliminates the Bible's anthropomorphic mention of the Deity's "eyes" and its use of the designation "Lord" (on Josephus' virtually complete avoidance of "Lord" as a divine title, see Begg 1993:45, n 218). 
happened."32 To this directive Josephus attaches what appears to be an editorial notice inspired by David's reference to the two priests' sons in his address to Zadok of 15:27: "In all these matters he had as his faithful aids (mıotous ... Sıøkóvous) Achimas, ${ }^{33}$ the son of Sadok, and Jonathan the son of Abiathar." 34

The biblical account of David's encounter with the clergy (15:24-29) concludes in $\vee 29$ with the notice that Zadok and Abiathar carried the ark of God back to Jerusalem and they [MT; LXX B: it, the ark] remained there; [LXX $L$ : and it (the ark) returned there]." Leaving readers to supply this item for themselves, Josephus moves directly to his (delayed) version of David's encounter with "Ittai".

\subsection{Encounter with Ittai}

As the first of the fugitive David's five encounters, 2 Sm 15:19-23 tells at some length of the king's meeting with Ittai ("Ethis")"E $\theta_{1 S}$ ) 35 : David urges him to return (vv 19-20), Ittai professes his devotion to the king ( $v 21$ ), David allows him to accompany him ( $v 22$ ), and the whole segment concludes with mention of David's crossing the brook Kidron ( $v 23$ ). The extent of this segment seems out of proportion to Ittai's significance for the further course of the story (in 2 Sm 18:3, 5 [// Ant 7.233] there is passing reference to Ittai as one of the three commanders among whom David divides up his army). Accordingly, I suggested that Josephus may have placed it after David's more "consequential" meeting with the clergy, reversing the order of 15:19-23 and 15:24-29 in doing so. In addition, however, the historian drastically reduces the whole "Ittai episode" in his version of this in 7.201b: "Ethis ("E0,s) the Gittite (Гıттаios) ${ }^{36}$ also set out with him, ${ }^{37}$ having overcome the objections of

\footnotetext{
${ }^{32}$ In 15:28 David simply mentions that he will await information from Zadok and the two priestly sons. Josephus' king is more directive in his commanding the clergy to provide him with intelligence.
}

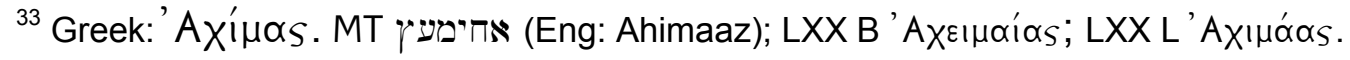

${ }^{34}$ Josephus' above rendering of 2 Sm 15:27 resolves the difficulty of the biblical text where David commands Zadok: “... go back (pl) to the city in peace and Ahimaaz your son and Jonathan the son of Abiathar, your two sons with you," even though only one of the two sons is Zadok's own (RSV supplies the words "and Abiathar" after "in peace" in order to alleviate the problem).

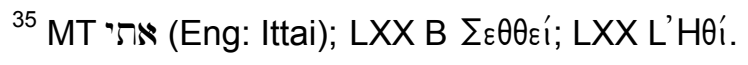

${ }^{36}$ This is the reading of the codex O; Nodet follows the reading of RMSP, that is Гıt $\theta$ aios; Lat has iettheus.

${ }^{37}$ This notice anticipates the outcome of the exchange between David and Ittai (15:19-22a) as recorded in 15:22b: "So Ittai ... passed on, with all his men and all the little ones with him (MT; LXX B: all his servants and the whole crowd with him; LXX L: and all his servants and the king and all the men with him)."
} 


\section{David's flight from Jerusalem}

David who had tried to persuade him to stay ( $\mu^{\prime} \varepsilon v \varepsilon ı$... ơ $v^{\prime} \varepsilon \pi \varepsilon \mid \theta \varepsilon^{38}$ ), ${ }^{39}$ and in this way he showed his loyalty (Eüvous) even more clearly."

\subsection{Encounter with Hushai}

The central encounter of David's five meetings on his way to the Jordan comes in 15:30-37 where the king converses with "Hushai the Archite" on the Mount of Olives.

The account of the pair's actual encounter (15:32-37) is preceded by notices on the movements of king and people (15:30) and on David's being informed of Ahithophel's adherence to the rebel Absalom and his prayer that God vitiate Ahithophel's "counsel” (15:31). Josephus' rendering of this opening sequence is 7.202. His description (7.202a) of the party's progress omits several of the pathetic details cited in 15:30: "Now as David was ascending the Mount of Olives, ${ }^{41}$ with bare feet ${ }^{42}$ and with all his company in tears ...." ${ }^{43}$ Conversely, he elaborates considerably $(7.202 b)$ on David's reaction to the news of Ahithophel's defection (// 15:31): “... news was brought to him that Achitophel was with Absalom and now belonged to his party. ${ }^{44}$ And

\footnotetext{
${ }^{38}$ This phrase both echoes and stands in contrast with the reference to David's (successfully) "persuading" the clergy "to remain" ( $\left.\mu^{\prime} \varepsilon v \varepsilon ı v^{\prime} \varepsilon \pi \varepsilon I \sigma \varepsilon v\right)$ in 7.200.

${ }^{39}$ By means of this brief notice Josephus sums up the extended exchange between David and Ittai in 15:19-22a.

${ }^{40}$ This editorial comment about Ittai's fidelity to David being still more evident in his refusal to let himself be persuaded by the king's urging him to return has no direct counterpart in 15:1923. Josephus could, however, have find an inspiration for his characterization of Ittai in the latter's words to David as cited in 15:21: "As the Lord lives, and as my lord the king lives, wherever my lord the king shall be, whether for death or for life, there also will your servant be" with its declaration of unconditional loyalty.
}

\footnotetext{
${ }^{41}$ Josephus' explicit mention of the "mount (opous) of Olives" has a counterpart in $\operatorname{Tg}$ 15:30 ("the ascent of the Mount of Olives"), whereas MT and LXX BL speak of the "ascent (LXX a $v \alpha \dot{\beta} \beta \sigma / v)$ of Olives."
}

${ }^{42}$ Compare the more elaborate description of the fugitive king "weeping as he went (MT; LXX L: and he wept; LXX B lacks an equivalent to this opening phrase), barefoot and with his head covered" given in 15:30a. (Num Rab 3.2 and Midr Sam 8.2, e g, interpret the mention of David's head being "covered" as indicative of his excommunicated status; that excommunication was lifted by David's teacher Ira the Jairite [cf $2 \mathrm{Sm}$ 20:26] "who brought the king near," i.e. to God).

${ }^{43}$ Compare the more expansive description given in 15:30b: "and all the people who were with him covered their heads, and they went up, weeping as they went."

${ }^{44}$ Ahithophel's joining of Absalom's revolt has been reported previously by Josephus in Ant 7.197 (// $2 \mathrm{Sm} 15: 12)$. 
when David heard this, his grief was intensified ${ }^{45}$ and he called upon God, ${ }^{46}$ beseeching Him to alienate Absalom's feeling from Achitophel, ${ }^{47}$ for he feared

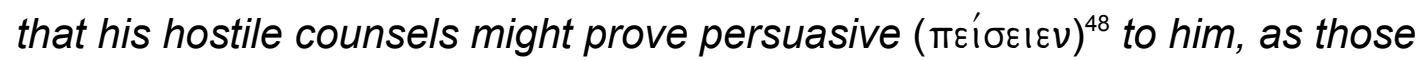
of a man of ready wit ( $\phi \rho \varepsilon v i n \rho \eta s)^{49}$ and quick to see an advantage."

Following the interlude of 15:31, 15:32 resumes the account of David's movements from 15:30: at this point the king reaches "the summit" (i e of the "ascent of the Olives," 15:30) where he is met by the disheveled Hushai. Josephus accentuates (7.203a) the poignancy surrounding this new encounter: "And when he reached the crest ( $\hat{\eta} s$ kopu $\phi \hat{\eta} s)^{51}$ of the mountain ( Toû ópous), ${ }^{52}$ he gazed upon the city and with many tears, ${ }^{53}$ as if already

\footnotetext{
${ }^{45}$ These preliminaries to David's invocation of God in response to the news of Ahithophel's defection lack a counterpart in 15:31.

${ }^{46}$ In 15:31b David addresses the Lord in direct address.

${ }^{47}$ In 15:31b David's prayer is rather that God "turn the counsel of Ahithophel into foolishness

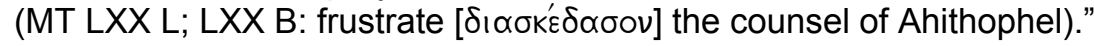

${ }^{48}$ This term echoes the references to David's attempted "persuadings" of the clergy (7.200), Ittai (7.201), and (subsequently) Hushai (7.204). A persuasive speaker himself, David is all the more concerned about the impact Ahithophel's similar capacities might have.

${ }^{49}$ This adjective is hapax in Josephus.

${ }^{50}$ The above motivation for David's appeal in terms of the threat posed by Ahithophel's acuity and persuasive powers lacks a parallel in 15:31 itself. It might, however, be inspired by the editorial remark of 2 Samuel 16:23 (a passage not reproduced by Josephus in its biblical context) according to which "Now in those days the counsel which Ahithophel gave was as if one consulted the oracle (literally: word) of God; so was all the counsel of Ahithophel esteemed both by David and by Absalom."

${ }^{51}$ With this common noun Josephus translates the term הראש ("the summit") of MT 15:32. LXX BL, by contrast, render, that word as a proper place name, i e (' $\left.\varepsilon \omega_{s}\right)$ toû 'Pow's. B Sanh 107b develops a midrash around the use of the term ראש (literally:"head") in MT 15:32 where it stands in connection with a reference to "worshiping God". The starting point of the Talmud's construction (which is attributed to R Judah speaking on behalf of Rab) is the use of the same term in Daniel 2:34 to denote the golden "head" of Nebuchadnezzar's idolatrous statue. Combining the two texts, $R$ Judah declares that David was on the point of worshiping idols when Hushai intervened to point out the infamy such an action would bring on him. In reply David avers that it is better that he should do this in that people would then attribute his slaying at the hands of Absalom to God's vengeance for his (David's) misdeed rather than to God's inability to defend him against his rebel son.

${ }^{52}$ This indication (which picks up on the phrase used in 7.202) lacks a counterpart in MT and LXX BL 15:32. It does, however, have a parallel in both Tg and Vulg.

${ }^{53}$ The reference to David's "tears" has no equivalent in 15:32 itself. It might, however, be seen as a delayed utilization of the mention of David's "weeping" during his ascent in (MT LXX L) 15:30 (see above). 


\section{David's flight from Jerusalem}

fallen from royal power, prayed to God. ${ }^{54}$ Then there met him a man who was

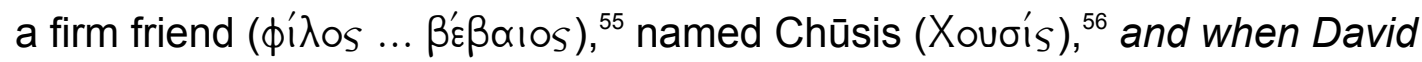
saw him with his garments rent and his head covered with ashes, ${ }^{57}$ weeping

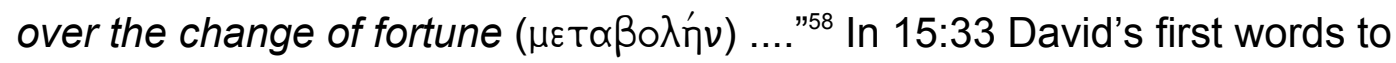
the grieving Hushai are the curt statement: "If you go on with me, you will be a burden to me." Reserving for a later point his version of this remark, Josephus begins (7.204b) by portraying a more empathetic king: “... he comforted him and exhorted him to cease grieving ...." Only thereafter, does he have David inform Hushai of what he has in mind for him (// 15:34): “... and finally, implored him $^{59}$ to go back to Absalom and under pretence of being on his side, ${ }^{60}$ in order to discover his secret plans ${ }^{61}$ and oppose the counsels of Achitophel." ${ }^{2}$ To this proposal by the king he then attaches his (attenuated) version of David's opening comment of 15:33 (see above): "He (Hushai)

\footnotetext{
54 Josephus' mention of David's "praying to God" on the summit corresponds to the notice on the king's "worshiping the Lord" there in LXX L 15:32a (see also VL's cum orasset ibi Dominum). In the other witnesses (e g, MT) is uncertain whether a worshiping by David in particular or a more generalized customary worship (thus RSV: "[the summit] where God was worshiped") is being referred to.
}

${ }^{55}$ This qualification of "Hushai" has a counterpart in the plus of $L X X B L 15: 32 b$, where in a anticipation of 15:37 (MT and LXX), the figure is called 'ETaipos $\triangle \alpha u \varepsilon^{\prime} \delta$ (see also VL's princeps amicorum David).

${ }^{56}$ MT חושי (Eng: Hushai); LXX BL Xovøzí. Josephus omits his biblical gentilic, that is "the Archite".

${ }^{57}$ According to $2 \mathrm{Sm}$ 15:32b Hushai had "earth" on his head. Josephus' indication on the matter recalls $2 \mathrm{Sm} \mathrm{13:19//} \mathrm{Ant} 7.171$ where, following her rape by Amnon, Tamar pours "ashes on her head".

${ }^{58}$ Josephus' mention of Hushai's "weeping" is an addition to the presentation of him in 15:32. The addition establishes a parallel between him and the king who in 7.203 is described as praying "with many tears, as if already fallen from royal power."

${ }^{59}$ In 15:33 David uses direct address with Hushai. Here again, Josephus prefers indirect discourse.

${ }^{60}$ Compare the protasis of David's conditional statement to Hushai in 15:34a: "But if you return to the city, and say to Absalom [LXX BL have a long plus at this point, reading "your brothers have left and king was left after me - your father - and now" which McCarter (1984:367) regards as original, but to which Josephus has no equivalent. LXX L repeats this same plus after 15:36] 'I will be your servant, O king; as I have been your father's servant in time past, so now I will be your servant ...."

\footnotetext{
${ }^{61}$ This element of the Josephan David's initial proposition to Hushai has no counterpart in 15:34 (see next note). It does, however, look forward to David's additional proposal concerning Hushai's keeping him informed in 15:35-36.
}

${ }^{62}$ Compare the apodosis of David's word to Hushai in 15:34b: “... then you will defeat for me the counsel of Ahithophel." 
would not, said David, be of as great help to him by coming along, ${ }^{63}$ as he might be by staying with Absalom."

David's instructions to Hushai continue in 15:35-36 where he enjoins him to keep him informed of developments by using the two priestly sons (see 15:27) as a liaison. Josephus has already anticipated this element of David's proposition in his rendition of 15:34, and so does not reproduce the content of $15: 35-36$ at this juncture. Instead, he proceeds immediately (7.204c) to his version of the conclusion (15:37) to the David-Hushai encounter of 15:30-37:

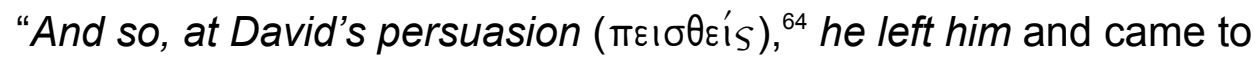
Jerusalem, where not long after, Absalom also arrived." 65

\subsection{Encounter with Ziba ${ }^{66}$}

David's fourth encounter, as recorded in 2 Sm 16:1-4 (// 7.205-206), involves Ziba, the steward of Mephibosheth, the son of Jonathan. 2 Sm 16:1 represents Ziba meeting David once the king has passed "a little beyond the summit" (i e of the Mount of Olives, see 15:30,32) with a pair of asses and a variety of provisions. Josephus' rendition (7.205a) provides an expanded identification of Ziba, while making only general allusion to the supplies he brings with him: "Now David had gone on a little further when he was met by Siba, the servant of Memphibosthos, ${ }^{67}$ whom David had sent to take charge of the property which he had presented to the son of Jonathan, the son of Saulp; Siba had with him a couple of asses laden with provisions ...."69

\footnotetext{
${ }^{63}$ With this formulation, Josephus' David tones down the unqualified (and unappreciative) words attributed to the king in 15:33: "If you go on with me, you will be a burden to me." His David acknowledges that Hushai's accompanying him would indeed be of some "help" to him - albeit not as great as the help he would render him by returning to Absalom.

${ }^{64}$ This opening phrase has no counterpart in 15:37. It recalls the theme of David the persuader introduced by Josephus in his version of the king's two previous encounters: see 7.200 (David "persuades" the clergy to remain behind) and 7.201 (Ittai overcomes "the objections of David who had tried to persuade him to stay").

${ }^{65}$ In 15:37 the two men's arrival in Jerusalem is depicted rather as simultaneous: "So Hushai ... came into the city, just as Absalom was entering Jerusalem." Josephus has no equivalent to the LXX L plus at the end of 15:37: "and Ahithophel was with him (Absalom)."

${ }^{66}$ On Josephus' version of the various biblical accounts concerning David's interactions with Ziba and his master Mephibosheth (see Begg 1998).

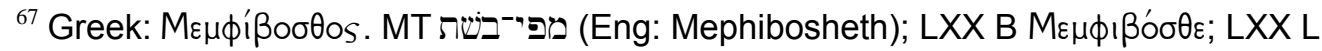

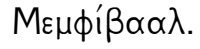

${ }^{68}$ This appended phrase reminds readers of the measures taken by David with regard to Mephibosheth and Ziba as related in Ant 7.114-115 (// 2 Sm 9:7-10).

${ }^{69} 2 \mathrm{Sm}$ 16:1 (MT) specifies "two hundred loaves of bread, a hundred bunches (LXX L: an ephah) of raisins, a hundred ( $L X X L$ two hundred) of summer fruit ( $L X X B L$ : dates) and a skin of wine."
} 
2 Sm 16:2 recounts an exchange between David and Ziba in which the king asks about the things Ziba has brought and the latter replies, specifying the intended purpose of the various items he has with him. Leaving aside David's opening question, Josephus has Ziba speak on his own volition: “... (provisions) from which he bade $\left({ }^{\prime} \varepsilon \kappa^{\prime} \lambda \varepsilon \cup \sigma \varepsilon\right)^{70}$ David take whatever he himself and his men might need."71

The exchange between David and Ziba takes a new turn in 16:3a where the king inquires about the whereabouts of "your master's son." Josephus' rendering (7.206a) clarifies the ambiguity concerning the person alluded to in the biblical David's question (where "master" might refer to Ziba's current "owner" Mephibosheth and "son" to the latter's progeny "Mica" [see 2 Sm 9:12], or, alternatively, to Ziba's previous overlord Saul [see 2 Sm 9:2] and his (grand)son Mephibosheth, respectively): "And when he was asked where he had left Memphibosthos ...."72

In response to David's query, Ziba avers (16:3b) that the object of his inquiry has stayed in Jerusalem, and then quotes his (purported) words: "Today the house of Israel will give me back the kingdom of my father." Josephus, who has hitherto abbreviated the account of Ziba's encounter with David (16:1-4), expatiates on the former's reply: "he said, 'in Jerusalem, where he was waiting to be chosen king in the midst of the prevailing confusion in recognition of the benefits which Saul had conferred on the people."73

\footnotetext{
${ }^{70}$ Josephus' use of this term on the lips of a subordinate like Ziba is noteworthy - as his having him initiate the exchange - given his customary concern for proper royal protocol. The peculiarity of his presentation here highlights the precariousness of David's position at the moment - even someone of Ziba's status can "command" the fugitive king.

${ }^{71}$ In his reply to David of 16:2b Ziba differentiates among the various items he has brought and their intended purposes: "the asses are for the king's household to ride on, the bread and summer fruit for the young men to eat, and the wine for those who faint in the wilderness to drink." Having previously generalized the list of supplies accompanying Ziba in 16:1, Josephus treats Ziba's statement concerning these of 16:2b similarly.

72 In 16:3a David asks "where is your master's son?" Josephus wording ("where he had left ...") highlights both the crippled Mephibosheth's dependence on Ziba for his mobility and the latter's responsibility towards the former.

${ }^{73}$ Josephus' appendix to Mephibosheth's (alleged) word suggests a double basis for his entertaining such (seemingly farfetched) hopes for himself i e the current political disorder (in which anything might happen) and the still living memory of Saul's merits which would favorably dispose people towards the claims of his grandson. (In mentioning Saul by name here, Josephus disposes of an ambiguity involved in Ziba's quotation of Mephibosheth's word in 16:3 where the latter looks forward to getting back the "kingdom of my father": is the "father" in question Mephibosheth's actual father, Jonathan, who never held the kingship, or rather his grandfather King Saul? For a similar problem and its handling by Josephus, see above in the text.
} 
The Ziba-David encounter concludes summarily in 16:4 with David awarding Ziba the property he had previously conferred on Mephibosheth ( $v$ 4a) and Ziba's expression of submission and hopes for David's future favor (v 4b). The historian's version (7.206c) elaborates on David's decision, while

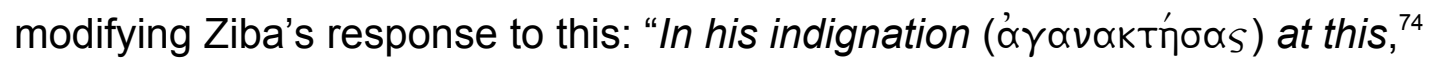
David made a present to Siba of all that he had granted to Memphibosthos, ${ }^{75}$ for, he said, he had a far juster claim to possess them than had the other. ${ }^{76}$

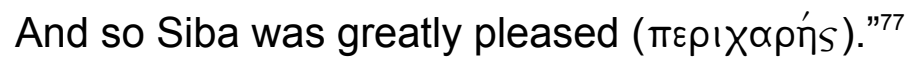

\subsection{Encounter with Shimei}

David's final encounter on his way to the Jordan as related in 2 Sm 16:5-13 (// Ant 7.207-210a) is a much more negative occurrence than the four previous ones wherein the king is subjected to verbal abuse by Saul's supporter Shimei. MT 2 Sm 16:5-6 places the encounter at "Bahurim" where David is cursed and pelted with stones by his adversary in the presence of the king's adherents. Josephus' name for the encounter site in 7.207a apparently reflects that used in LXX L (and VL) 16:5: "When David came to Chōranos, ${ }^{78}$ as the place was called, there came out a relative of Saul, ${ }^{79}$ named Samūis is

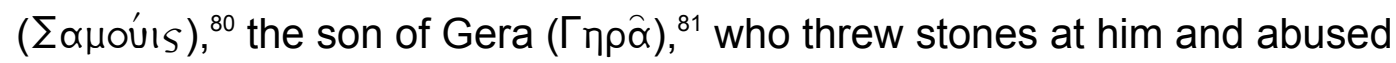

\footnotetext{
${ }^{74}$ Such inserted allusions to the emotional states that prompt characters' words and actions is a recurrent feature of Josephus' rewriting of the Bible.

${ }^{75}$ Compare David's direct address word to Ziba in 16:4a: "Behold all that belonged to Mephibosheth is now yours."

${ }^{76}$ Josephus here supplies an explicit motivation for David's decision which in 16:4a itself is left without any such motivation. The addition highlights the king's sense of justice that animates the legal decision he makes.

${ }^{77}$ Compare 2 Sm 16:4b: "And Ziba said, 'I do obeisance (Tg.: I am giving thanks; LXX B: Ziba said as he did obeisance); let me ever find (MT LXX B; LXX L: I have found) favor in your sight, my lord the king."' Josephus' substitution of a reference to Ziba's emotional state establishes a parallel between him and David whose own emotions ("indignation") on this occasion are also reported by the historian.

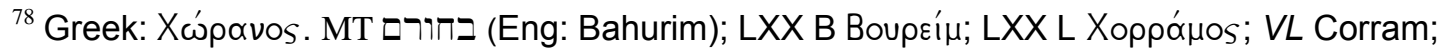
Vg. Baurim; Tg. translates MT's form with the Aramaic word עלם, meaning "youth." In 7.225 when rendering 2 Samuel 17:18's reference to "Bahurim," Josephus calls the site Bokхорńs (Schalit [1968:s $v$ ] reads this same form also in 7.207.

${ }^{79} 2$ Samuel 16:5: "a man of the family of the house of Saul."

${ }^{80}$ MT שמעי (Eng: Shimei); LXX BL $\sum \varepsilon \mu \varepsilon \varepsilon i ́$.

${ }^{81}$ MT גר:; LXX BL 「пра́.
} 


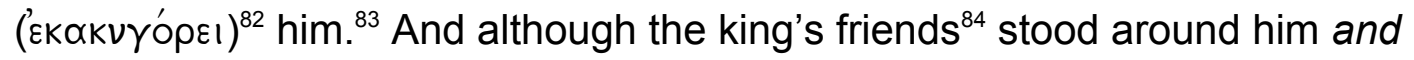
protected him...." 85

2 Sm 16:7-8 cites Shimei's denunciation of David at length. Josephus' version (7.207b-208b) rearranges and rewords the content of his speech, likewise recasting it in indirect discourse:

(7.207b) ... Samūis only continued the more to curse him and

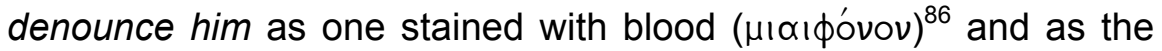

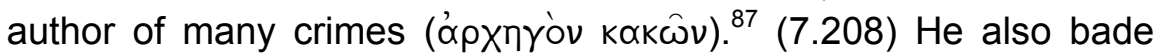
him leave the country ${ }^{88}$ as one under a ban and accursed ('Evari

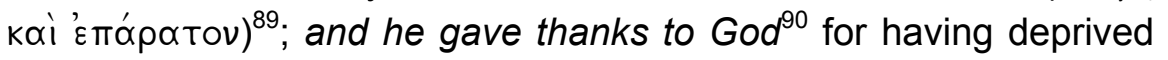
David of his kingdom and for having exacted punishment of him, through his own son, for the crimes which he had committed against his master. ${ }^{91}$

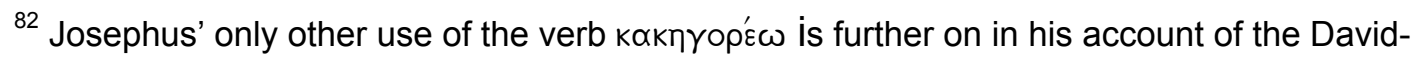
Shimei encounter (see 7.210).

${ }^{83}$ Josephus reverses the sequence of $16: 5 b \beta-6 a$ where Shimei's "cursing continually" is mentioned prior to his "throwing stones" at David. He leaves aside the indication of 16:6a that Shimei was stoning "all the servants of King David" as well.
}

${ }^{84} 2 \mathrm{Sm}$ 16:6b: "all the people and all the mighty men." Mention was already made of David's "friends" at the start of Josephus' account of David's flight in 7.199.

${ }^{85}$ In 16:6b the reference is simply to David's attendants being "on his right hand and on his left." Josephus' addition gives them a more active role in David's regard.

${ }^{86}$ Josephus uses this adjective twice elsewhere, that is in $B J 4.159,163$. The term is his equivalent to Shimei's double designation of David as "man of blood" at the beginning (16:7) and end (16:8) of his biblical speech to him.

${ }^{87}$ Josephus' one remaining use of this expression is in Ant 20.126 (in reference to the Samaritans). In MT 2 Sm 16:7 Shimei calls David איש הבליעל (RSV: "you worthless fellow"), rendered in LXX BL as ávìp o mapóvouos ("lawless man").

${ }^{88}$ The biblical Shimei begins his speech to David in 16:7 with the double imperative "begone, begone."

${ }^{89}$ This collocation occurs only here in Josephus (he uses both of its component terms twice

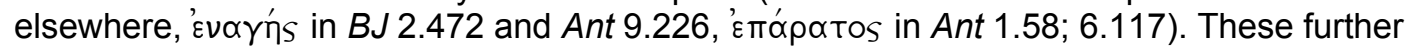
words of insult have no clear counterpart in Shimei's speech to David of 16:7-8. They may, however, reflect the tradition, attested elsewhere in Jewish midrashic writings, that David had been "excommunicated" prior to his flight from Jerusalem.

${ }^{90}$ Shimei's speech in 2 Samuel 16:7-8 does not include such a "thanksgiving".

91 Josephus rearranges the sequence of Shimei's words in 16:8a: "The Lord has avenged upon you all the blood of the house of Saul [compare Josephus: all the crimes which he (David) has committed against his master (Saul)], in whose place he had reigned; and the Lord has given the kingdom into the hand of your son Absalom." In his version, David's loss of his kingdom is mentioned in first place, and Absalom is assigned an active role in God's punishing of David. 
Following Shimei's tirade (16:7-8), David's henchman Abishai addresses the king (16:9) with a derogatory reference to Shimei as "a dead (MT LXX B; LXX $L$ accursed) dog" and a proposal that he (Abishai) behead him on the spot. The historian's rendition (7.208b) interjects mention of the emotional state, not only of Abishai, but of all those accompanying the king: "Though they were all provoked to anger ('opүîs) at him, ${ }^{92}$ especially Abisai, ${ }^{93}$ who wished to make an end of him ...."94

David's reply to Abishai comes in 2 Sm 16:10-12. Josephus prefaces his version with an editorial note that concludes 7.208: “... David restrained his [Abishai's] anger (ópү̄̄s) ...." Thereafter, he cites (7.209) David's words in the following rearranged and contentually modified form ${ }^{95}$ :

Let us not add to our present ills (kakois) ${ }^{96}$ by causing new ones to arise, for certainly no feeling of shame or concern touches me on

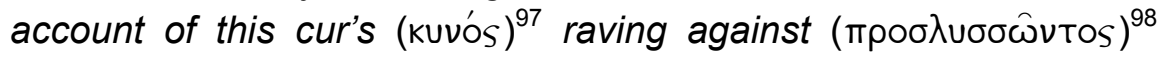
me ${ }^{99}$; but I submit to $\mathrm{God}^{100}$ by whom this fellow has been moved to

\footnotetext{
${ }^{92}$ Compare Josephus' (likewise interjected) mention of David's "indignation" in the face of Ziba's report about Mephibosheth in 7.206.

${ }^{93}$ Josephus omits the designation of Abishai as "son of Zeruiah" given in 16:9.

${ }^{94}$ Josephus reformulates Abishai's direct address proposal to David of 16:9b ("let me go over and take off his head") in more general terms, likewise turning it into an editorial notice about what the retainer "wished" to do.

${ }^{95}$ In his version of David's speech of 16:10-12, Josephus, exceptionally, retains the Bible's direct address; compare n 29.

${ }^{96}$ This term picks up on Shimei's denunciation of David as the "author of many crimes $(\kappa \propto \kappa \omega \hat{v}) "$ in 7.207.

${ }^{97}$ In 2 Sm 16:9 it is Abishai who calls Shimei a "dead (LXX L accursed) dog (LXX BL kúwv)." Josephus confers added weight on the denigration of Shimei implied by the term in having David himself apply it to his tormentor.

${ }^{98}$ The verb $\pi \rho \circ \sigma \lambda$ $\sigma_{\sigma o \alpha} \omega$ is hapax in Josephus.

${ }^{99}$ David's above opening words take the place of the (obscure) question with which he commences his reply to Abishai in 16:10a: "What have I to do with you (pl), you sons of Zeruiah?" (MT LXX B; LXX L: what have I to do with you [sg], you son of Zeruiah?").

Josephus' substitute opening depicts David as exhorting his whole party ("us") to refrain from any further offence, while also affirming his own sense of security and serenity in the face of Shimei's abuse.

${ }^{100}$ Compare the fugitive David's earlier statement of submission to the Deity in 7.199: "he committed the entire matter into the hands of God as judge." The affirmation here in 7.209 has no direct counterpart in David's words in 16:10-12; it does, however, reflect the whole tenor of the king's discourse there.
} 


\section{David's flight from Jerusalem}

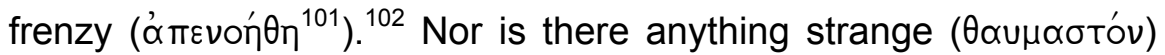
in my being so treated by him, when I have experienced the impiety ('œoєßoûs) ${ }^{103}$ of a son. ${ }^{104}$ Nevertheless, God's compassion (oîkTos) will rest on us, and we shall overcome our enemies by His will. ${ }^{105}$

The "Shimei episode" (2 Sm 16:5-13) concludes in verse 13 with the reprobate's cursing, throwing stones, and "flinging dust" as he and David's party proceed along parallel paths. The historian's version (7.210a) highlights David's sovereign disregard of Shimei's provocations, while likewise leaving aside the latter's use of stones and dust to accompany his verbal curses: "And so he continued on his way, ${ }^{106}$ taking no notice of Samūis, ${ }^{107}$ who ran along

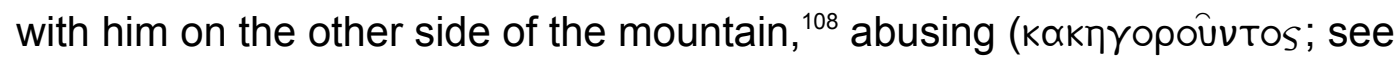

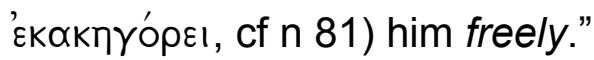

\subsection{Arrival at the Jordan}

In 16:14 David's flight comes to a provisional end with his party halting and the king's "refreshing himself." In line with the plus of two LXX L manuscripts

\footnotetext{
${ }^{101}$ This verbal form recalls the noun ámóvola ("madness") which David uses in reference to Absalom's rebellion in 7.199.

${ }^{102}$ The biblical David twice alludes to God's (possible) involvement in Shimei's cursing: see 16:10: "... and if (MT ketiv; MT qere LXX BL: because) the Lord said to him [Shimei] 'curse David ..." and 16:11b "(let him alone and let him curse); for the Lord has bidden him." Josephus' David limits himself to a single such allusion.

${ }^{103}$ This adjective echoes the noun ơøeßzí used of Absalom's initiative by David in 7.198.

${ }^{104}$ Compare David's declaration in 16:11aß: "Behold, my own son seeks my life; how much more now may this Benjaminite." Josephus reverses the sequence of this statement's two components in his version. He likewise leaves aside the new, seemingly superfluous, introductory formula of 16:11a: "And David said to Abishai (LXX L: Joab) and to all his servants."
}

${ }^{105}$ David's speech concludes in 16:12 with his expressing a more tentative and indeterminate hope regarding God and himself: "It may be that the Lord will look upon the affliction [RSV reads in accordance with LXX here; the MT ketiv has on my iniquity (בעוני), the qere on my eye (בעיני); cf Tg. what if the tear of my eye is revealed before the Lord?], and that the Lord will repay with good for this cursing of me today." In addition, Josephus' version extends the king's expression of hope to encompass, not just himself, but his whole party ("us").

\footnotetext{
${ }^{106}$ Compare 16:13aa: "David and his men went on the road." Josephus keeps attention focussed on the king and his movements.

${ }^{107}$ In his disregard of Shimei's taunts, David acts in accordance with his call to avoid further offences and his submitting himself to God in his words of 7.209.

${ }^{108}$ Compare 16:13: “... Shimei went along on the hillside opposite him (David) ....”
} 
(19 108), ${ }^{109}$ Josephus (7.210b) supplies mention of the party's halting place, likewise highlighting the king's solicitude for his supporters in their wearied state: "And, when he reached the Jordan, ${ }^{110}$ he allowed his weary men to rest there." $" 111$

\section{CONCLUSION}

At the conclusion of this study I return to my three opening questions in order to summarize my findings on them. On the first question, concerning the text form(s) of 2 Sm 15:13-16:14 utilized by Josephus in Ant 7.198-210, the study yielded rather mixed results. Like MT, he lacks an equivalent to $L X X B L$ 's opening plus in the words David asks Hushai to convey to Absalom, just as he translates (7.202) MT's form הראש ("the summit"), rather than transliterating this as a proper place name à la LXX BL.

On the other hand, in common with LXX BL 15:31 he has David informed (see 7.202) of Ahithophel's joining Absalom, whereas in MT the king announces this himself. Again, like LXX BL 15:32, he designates (7.204) Hushai as David's "friend" when first presenting him. Moreover, his version of David's speech in response to Shimei's abuse (7.209) seems to reflect the king's allusion to his "affliction" as that which may prompt God's intervention on his behalf in LXX BL 15:12, as opposed to David's invocation of his own "iniquity" in the MT ketiv of that verse. In speaking of David's climbing "the Mount of Olives" he agrees with Tg. 15:30, as against MT and LXX's reference to "the ascent of olives." Similarly, his specification that the "summit" reached by David (7.203) was that of "the mount" has a counterpart in the plus of Tg. and Vulg. 15:32. He agrees (7.200) with MT LXX B 15:24 contra LXX L in mentioning "Abiathar" by name in his listing of the clergy who appear before the fugitive David (on the other hand, however, he does not follow the former witnesses in attributing a particular action to Abiathar [he ascended/ offered a holocaust] on this occasion). With MT and LXX B 15:37 he also lacks an equivalent to LXX L's reference to Ahithophel's entering Jerusalem along with Absalom. By contrast, in specifying that David "prayed to God" at the summit (7.203) Josephus aligns himself with LXX L (and VL) 15:32, whereas MT and

\footnotetext{
109 These two manuscripts have the phrase "beside the Jordan" following the reference to David and his party's "arriving weary" in 16:14. On the textual question here, see the commentaries cited in note 2 .

${ }^{110}$ Mention of this site as the (provisional) terminus of David's flight echoes the notice on David's "deciding to flee to the country across the Jordan" in 7.198.

111 In MT 16:14b the subject of the "self-refreshing" is David (alone), while in LXX (and Vulgate) a plural verb, referring to the whole of David's party, is used. Josephus highlights both David's magnanimity and his control of the situation: he permits his men to rest at the Jordan.
} 


\section{David's flight from Jerusalem}

LXX B leave the subject of the "worshiping" at the site indeterminate. His form ("Chōranos," 7.207) of the name of the locality where Shimei confronts David likewise seems to reflect that read by $L X X L 16: 5$, that is Xoppó $\mu$. Finally, in accord with two LXX L manuscripts in 16:14 he cites "the Jordan" as David's provisional halting-place in $7.210 \mathrm{~b}$. These findings suggest, in any case, that Josephus had various text-forms of $2 \mathrm{Sm} \mathrm{15:13-16:14} \mathrm{available} \mathrm{in} \mathrm{composing}$ Ant 7.198-210. ${ }^{112}$

My second opening question had to do with the rewriting techniques applied by Josephus to the biblical pericope and the distinctiveness of his own version that results. Prominent among the rewriting techniques in evidence throughout 7.198-210 are the historian's additions to/amplifications of source data. Instances include: the insertion concerning David's inner reaction to the news of Absalom's revolt (7.198, compare 15:13-14); the emotions surrounding the king's prayer that God frustrate Ahithophel's schemes (7.202, compare 15:31); David's "comforting" the distraught Hushai (7.204); the Rückverweis to David's earlier dealings with Ziba and Mephibosheth (7.205); the expansion of Mephibosheth's (purported) word as quoted by Ziba and of David's decision in response to this (7.206, compare 16:3b-4a); the interjected reference to the "anger" provoked by Shimei's cursing and David's "restraining" of this (7.208); and the allusion to David's ignoring Shimei's continued provocations (7.210a).

Conversely, Josephus either passes over entirely or notably abbreviates elements of the biblical presentation, especially when these involve repetition. Among examples of this technique we noted are the following: He does not reproduce the servants' protestation of loyalty to David of $15: 15$ and drastically compresses the repetitious enumerations of those accompanying the king of 15:16-18 in 7.199b. David's allusion to the possibility of God's "having no pleasure" in him (15:26) is left aside, as is the notice on the clergy's return to Jerusalem (15:29). The extended biblical account of the encounter between David and Ittai (15:19-23) is reduced to a single sentence (see 7.201b). Various particulars in the description of the king and people's ascent of the Mount of Olives of 15:30 are omitted in Josephus' version in 7.202. David's words to Hushai about the informatory role he envisages for the two priestly sons (15:35-36) likewise disappear in Josephus' rendition (7.204). A whole array of elements of the Ziba-David encounter as recounted in 16:1-4 are either suppressed or compressed in 7:205-206: the list of supplies Ziba brings with him (16:1) and David's question about these and Ziba's response (16:2). And finally, the historian abbreviates David's

\footnotetext{
${ }^{112}$ On the overall question of the text(s) of the Book of Samuel used by Josephus, see Ulrich (1989).
} 
repetitious statements concerning Shimei's abuse (16:10-12) in 7.209 , just as he dispenses with the mention of Shimei's pelting David's party with stones and flinging dust at them (16:13) in 7.210a.

Yet another Josephan rewriting technique on display in 7.198-210 is the historian's rearrangement of the sequence of the Bible's presentation. Under this head we noted, for example, his reversal of David's two initial encounters, that is first with Ittai (15:19-23) and then with the ark-bearing clergy (15:24-29) in 7.200-201 as well as his re-positioning of David's initial word to Hushai (see 15:33) within his version of the king's speech to that figure in 7.204.

In addition to the above three rewriting techniques, Josephus modifies/adapts the account of $2 \mathrm{Sm}$ 15:13-16:14 in still other ways. On the stylistic/terminological level, he (mostly) recasts biblical direct address as indirect and avoids using "(the) Lord" as a divine designation. Josephus' version also manifests numerous instances of more contentual modifications. The Josephan David initially responds to the report of Absalom's revolt with an internal reflection concerning this and only then summons his "closest friends" for a consultation (see 7.198-199a), instead of immediately addressing his servants about the necessity of flight as he does in 15:14. The six hundred men who join David in his flight are those who had been his companions during his pursuit by Saul (7.199b) rather than "Gittites who had followed him from Gath" (so 15:18). David expresses more definite hopes regarding his eventual vindication in 7.200 and 7.209 than does his biblical counterpart in 15:25-26 and 16:12b respectively. The king's statement concerning the intended role of the two priestly sons (15:27) becomes an editorial remark about the pair in 7.201a. David's prayer of 15:31 that God "turn into foolishness" (MT LXX L)/ frustrate (LXX B) Ahithophel's counsel is recast as an appeal that Absalom be alienated from Ahithophel (7.202). Hushai appears with "ashes" rather than "earth" on his head (compare 7.204 and 15:32). The brusqueness of David's assertion that Hushai would only be a "burden" to him if he accompanied him (15:33) is attenuated in Josephus' rendering (see 7.204). Hushai's arrival in Jerusalem comes "shortly after" (7.204), rather than simultaneously with Absalom's appearance there (thus 15:37). Ziba initiates the conversation between himself and David (7.205), rather than waiting to be questioned by the king, as he does in 16:2.

Subsequently, Ziba is "greatly pleased" with David's award to him (7.206), while in 16:4b he addresses David with words that express his submission and hopes for future royal favor. It is not Abishai alone, but all those accompanying David, who react to Shimei's provocations (compare 7.208 and 16:9). The "canine language" used by Abishai in reference to Shimei in 16:9 is 


\section{David's flight from Jerusalem}

placed by Josephus on the lips of David himself (see 7.209). Then, at the very end of the episode, David permits his tired men to relax (7.210b), rather than doing this himself (MT 16:14) or the whole party doing so (LXX BL 16:14).

What now can be said about the distinctiveness of Josephus' account of David's flight that results from his application of the foregoing rewriting techniques? Throughout, the historian "psychologizes" the proceedings, introducing recurrent references to characters' emotional states/reactions. His David uses explicitly negative language concerning Absalom's move against him in a way the biblical king does not (see 7.198,209 and cf $n$ 10). The David-Ittai encounter is de-emphasized by Josephus' placing of it in second rather than in first place in the sequence of the king's meetings and his notable abbreviation of the incident itself (compare 15:19-23 and 7.201b). In David's exchange with the clergy (7.200-201b// 15:24-29) the prominence of Zadok is reduced in favor of the clergy en bloc. At the beginning of his version of the Ziba-David encounter, the historian helpfully reminds (7.205a) readers of what he has previously recounted about those characters (and about Mephibosheth, who will figure prominently in what follows), thereby furthering the inner coherence of his vast work. The ambiguity as to which Saulide is being referred to in David's question of 16:3a and Ziba's response of 16:3b is resolved by means of the wording used by Josephus in 7.206. In similar fashion, Josephus also disposes of the obscurity surrounding David's opening question to Abishai ("what have I to do with you, you sons of Zeruiah?," 16:10a) by giving the king a new initial word in 7.209 .

Josephus' account of David's flight also shows its distinctiveness in its numerous retouchings of the biblical portrait of the fugitive king. Right at the start, the historian interjects an extended sequence (7.198) concerning David's emotional response to and critical evaluation of Absalom's revolt. The king's piety is accentuated in that his declaration of submission to God's judgment comes while he is still in Jerusalem (see 7.199b) rather than only at a later point. Throughout Josephus' version David's persuasive powers are underscored. He appears more self-confident with regard to his ultimate vindication than does his Scriptural counterpart (compare 7.200 and 15:25-26; 7.209 and 16:12) and more empathetic in his dealings with Hushai (compare 7.204 and 15:33). The king's "indignation" and his sense of justice motivate his decision regarding Mephibosheth's property (7.206) which in 16:4a is left without any explicit motivation. In the face of Shimei's taunts the Josephan David displays a still greater serenity and sense of security (see 7.209a), this causing him to disregard Shimei's abuse (7.210a). And lastly, the king's concern for the welfare of his supporters comes to the fore at the end of the narrative where he allows them to "rest" at the Jordan (7.210b; compare Mt 
16:14 where David alone "refreshes himself" once the halting place is reached). ${ }^{113}$

My final opening question asked about Josephus' treatment of $2 \mathrm{Sm}$ 15:13-16:14 in comparison with the passage's handling elsewhere in early Jewish-Christian tradition. In contrast to Pseudo-Jerome he does not, we noted, mention an unanswered prayer by Abiathar in the presence of the ark, just as he has nothing equivalent to the exchange between Hushai and David regarding the latter's intended "idolatry" on the Mount of Olives as related in $b$ Sanh 107b. On the other hand, in attributing (7.208) to Shimei the "unbiblical" charge about David's being "under a ban and accursed," Josephus was possibly influenced by the midrashic tradition according to which David was in an excommunicated state at the moment of his fleeing Jerusalem.

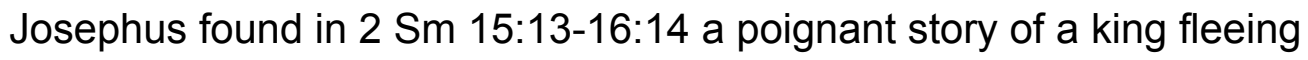
for his life from a rebel son, a story certain to appeal to Greco-Roman readers whose own literature featured many cases of dramatic changes of fortune, and accordingly he reproduces it in extenso. At the same time, however, he was clearly not content to simply repeat the story just as he found it in his biblical text(s). Instead, he invested considerable literary energy and ingenuity in developing a distinctive, "improved" version of the story in accord with his manifold purposes in retelling his people's history for a new time and a new audience.

\section{Works consulted}

Abegg, M Jr, Flint, P \& Ulrich, E 1999. The Dead Sea Scrolls Bible. San Francisco, CA: HarperSanFrancisco.

Anderson, A A 1989. 2 Samuel. Dallas, TX: Word Books. (Word Biblical Commentary 11.)

Begg, C T 1993. Josephus' account of the early divided monarchy (AJ 8, 212-420). Leuven: University Press. (Bibliotheca Ephemeridum Theologicarum Lovaniensium 108.)

Begg, C T 1998. David and Mephibosheth according to Josephus. Andrews University Seminary Studies 36, 165-82.

Begg, C T 2005. Flavius Josephus Judean Antiquities 5-7. Leiden: Brill. (Flavius Josephus Translation and Commentary 4.)

Brooke, A E, Maclean, N \& Thackeray, H St John 1928. The Old Testament in Greek II:III: I and II Samuel. Cambridge: University Press.

Caquot A \& de Robert P 1994. Les livres de Samuel. Genève: Labor et Fides. (Commentaire de l'Ancien Testament 6.)

Cross F M et al 2005. Qumran Cave 4 XII: 1-2 Samuel. Oxford: Clarendon Press. (Discoveries in the Judean Desert 17.)

Feldman, L H 1998. Josephus' interpretation of the Bible. Berkeley, CA: University of California Press.

${ }^{113}$ On Josephus' portrait of David overall, see Feldman (1998:537-569). 


\section{David's flight from Jerusalem}

Fernández Marcos, N \& Busto Saiz, J R 1989. El texto antioqueno de la Biblia Griega I: 1-2 Samuel. Madrid: C.S.I.C. (Textos y Estudios "Cardenal Cisneros" 50.)

Gryson, R 1994. Biblia sacra iuxta vulgatam versionem. Stuttgart: Deutsche Bibelgesellschaft.

Harrington, D J \& Saldarini, A J 1987. Targum Jonathan of the former prophets. Wilmington, DE: Glazier. (The Aramaic Bible 10.)

McCarter, P K Jr. 1984. II Samuel. Garden City, NY: Doubleday. (The Anchor Bible 9.)

Marcus, R 1934. Josephus, V: Jewish Antiquities, Books V-VIII. Cambridge, MA: Harvard University Press. (Loeb Classical Library.)

Morano Rodriguéz, C 1989. Glosas marginales de Vetus Latina en las Biblias Vulgatas Españolas: 1-2 Samuel. Madrid: C.S.I.C. (Textos y Estudios "Cardenal Cisneros" 48.)

Nodet, E 2001. Flavius Josèphe, III: Les Antiquités Juives Livres VI et VII. Paris: Cerf.

Polzin, R 1993. Curses and kings: A reading of 2 Samuel 15-16, in Exum, J C \& Clines, D J A (eds), The new literary criticism and the Hebrew Bible, 201-26. Sheffield: JSOT. (Journal for the Study of the Old Testament Supplement Series 143.)

Saltman A 1975. Pseudo-Jerome quaestiones on the book of Samuel. Leiden: Brill. (Studia Post-Biblica 26.)

Schalit, A 1968. Namenwörterbuch zu Flavius Josephus. Leiden: Brill.

Simpson, T F 1997. Paradigm shift happens: Intertextuality and a reading of 2 Samuel 16:5-14. Proceedings, Eastern Great Lakes and Midwest Biblical Society $17,55-69$.

Sperber, A 1959. The Bible in Aramaic, II. Leiden: Brill.

Ulrich E 1989. Josephus' biblical text for the books of Samuel, in Feldman, L H \& Hata, G (eds), Josephus, The Bible and history, 81-96. Detroit, MI: Wayne State University Press. 